\title{
Subnational constitutional courts and judicialization in Germany
}

\section{Werner Reutter ${ }^{1}$}

Accepted: 9 September 2020 / Published online: 19 October 2020

(C) The Author(s) 2020

\begin{abstract}
This paper examines the contribution of German subnational constitutional courts to the judicialization of politics in the German states, known as Länder. This research goal entails three dimensions. First, I have to define and measure judicialization. To accomplish this task, I use an index recently developed by an international group of scholars of comparative politics. Second, based on major theoretical approaches, I identify possible causes that might give reasons for judicialization, namely institutional preconditions and preferences of justices. In a third step, I use a linear regression in order to test the theory empirically and find links between causes and effects of judicial decision-making in subnational constitutional courts. The findings confirm institutionalist approaches that contribute to explaining decision-making in German subnational constitutional courts.
\end{abstract}

Keywords Constitutional adjudication · Constitutional courts · Federalism · Germany judicialization

\section{Introduction}

In 2011, Christoph Hönnige reported on a "major research gap" in comparative politics (Hönnige 2011: 355). On the one hand, he found that many scholars ascribe constitutional courts an "important role" in democratic systems (Hönnige 2011: 346). In this perspective, democracies show a strong tendency towards judicialization if these political systems have courts that can nullify laws (Lijphart 1999; Tsebelis 2002; Brouard and Hönnige 2017; Stone 1994). Ran Hirschl (2004: 73) even identified a "global trend toward juristocracy" which is "part of a broader process, whereby political and economic elites, while they profess support for democracy, attempt to insulate policymaking from the vicissitudes of democratic politics".

Werner Reutter

werner.reutter@rz.hu-berlin.de

1 Institut für Sozialwissenschaften, Humboldt-Universität zu Berlin, Unter den Linden 6, 10099 Berlin, Germany 
This would mean that a small elite replaces elected members of parliament. "[I]n the end," Alec Stone Sweet similarly concludes, "governing with judges" is equal to "governing like judges" (Stone Sweet 2000: 204). On the other hand, Hönnige (2011: 347) deplores the fact that we know "precious little about judicial systems outside the United States". And that seems to hold true for pretty much everything that concerns constitutional adjudication, at least according to Gibson et al. (1998) whom Hönnige calls as a witness to his case. Gibson et al. (1998: 343) stated that we "understand little or nothing about the degree to which various judiciaries are politicized; how judges make decisions; how, whether, and to what extent those decisions are implemented; how ordinary citizens influence courts, if at all; or what effect courts have on institutions and cultures."

Based on this discrepancy between assumed importance of and missing knowledge about constitutional adjudication, Hönnige (2011: 355) calls for more "comparative research about constitutional courts". Even further, this research should go "beyond judicialization" and include justices' preferences, macro-analytical perspectives as well as inter- and intra-institutional rules. In short, Hönnige argues for combining U.S.-originating rational choice theories, or strategic accounts regarding the causes of judicial decision-making, with European approaches concerning the effects of constitutional adjudication on politics. In this paper, I will respond to Hönnige's call—at least partly and in a specific way. Distinct from Hönnige's approach, I want to shed some light on a blind spot in the research on constitutional adjudication, namely on subnational constitutional courts. I hope to find out whether and how far German state constitutional courts contribute to what has been coined "judicialization" (Landfried 1984; Hirschl 2007: 169-210; Stone 1994). The judicialization hypothesis "assumes that courts reduce the ability of government and parliament to take purely political decisions" (Hönnige 2011: 347). At the same time, and as Hönnige (2011) suggested, I go "beyond the judicialization hypothesis" because I not only explore possible effects of court rulings on the legislature but I will also identify possible causes of such rulings. In short, I examine to which degree and for what reasons German state constitutional courts contribute to the judicialization of politics. In order to accomplish this task, I refer to neo-institutionalist approaches, that "seek to explain judicial decision-making as a process in which judicial values and attitudes are shaped by judges' distinct professional roles, their sense of obligation, and salient institutional perspectives" (Clayton 1999: 32).

My approach differs in two respects from other studies on constitutional courts. First, as already pointed out, I focus on subnational constitutional courts. I therefore use the comparative method to study courts of last resort in one country, in Germany. As Lijphart (1971: 683) has shown, the quality of any scientific explanation depends largely on how well we isolate the explanatory variables from those other variables that are presumed not to underlie the phenomenon we are trying to illuminate. Limiting my analysis to cases in one country meets this requirement and allows me to test theories in the framework of a most-similar systems design. Second, most research on judicialization has been based on a relatively small number of rulings that either support or refute the judicialization hypothesis depending on whether a court ruling nullifies a law or not. I will depart from this binary logic and try to capture potential effects of rulings in a more nuanced and differentiated way, 
namely by determining the degree of judicialization by means of a newly developed "strength index" that measures possible political reverberations of decisions made by subnational constitutional courts in Germany. However, before outlining the theoretical basis of my research as well as presenting and explaining the data and variables I will use in my analysis, a few remarks on German subnational constitutional courts are appropriate.

\section{German subnational constitutional courts: an overview}

I picked Germany not only because I am most familiar with the legal system in this country but also because Germany is a rather special case. It combines democracy, federalism, and a civil law tradition with a system of constitutional review at the national and subnational levels (Delledonne 2012: 298). In contrast to other countries with subnational high courts, German subnational constitutional courts have a mandate and obligation to enforce subnational constitutions and might thus contribute to the judicialization of politics. In consequence, the German system of constitutional adjudication provides the best preconditions for examining whether and how far subnational constitutional courts might encroach upon the competencies of the legislature. Even though this analysis will only include decisions taken by three courts, a general overview of the status, composition and competencies of the 16 German subnational constitutional courts provides a useful insight into the role these courts play in Germany's constitutional democracy and whether these institutions possess the capacity to lead to a judicialization of politics in the German states in the first place.

In terms of their status, and from a legal point of view, the 16 highest courts in the German states wield public powers and are as commensurate in rank with parliaments and governments in the states. All state constitutions include provisions relating to a constitutional court, its composition, competencies, and similar matters. Accordingly, all regional parliaments have passed laws on constitutional courts to put these constitutional stipulations into practice. As far as states comply with the homogeneity clause of Art. 23 para. 3 of Germany's Basic Law, they are entitled to establish a democratic order independently from the federation. The status of subnational constitutional courts differs from their national counterpart in several important respects, though. Their budgets are minimal and range between $€ 0.03$ million and $€ 1.007$ million in 2020 (Table 1). These limited budgets make it impossible for subnational courts to enjoy the status and many of the benefits of a large formal organization. In fact, many courts have neither clerks nor other support staff to manage workloads or prepare briefs for the justices, relying instead on the resources of other courts to which they are administratively affiliated (Wittreck 2006: 493-518; Starck 1983; Flick 2011: 17-76; Reutter 2020a).

Regarding composition, and in contrast to the Federal Constitutional Court (FCC), subnational courts of last resort consist of part-time or honorary justices ${ }^{1}$

\footnotetext{
1 I use the term "justice" only if I refer to members of state constitutional courts.
}

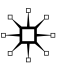


Table 1 German state constitutional courts: basic features. Source Author's compilation based on the budgets of the Länder and the federation; Federal Constitutional Court (2020: 1) and Reutter (2020a: 160)

\begin{tabular}{|c|c|c|c|c|c|c|}
\hline & $\begin{array}{l}\text { Established } \\
\text { in (year) }\end{array}$ & Seat & $\begin{array}{l}\text { Budget (2020; } \\
\text { in } 1000 €)\end{array}$ & $\begin{array}{l}\text { Number of staff } \\
(2016 / 2020)\end{array}$ & $\begin{array}{l}\text { Number of } \\
\text { justices }^{\mathrm{a}}\end{array}$ & $\begin{array}{l}\text { Incoming } \\
\text { cases per } \\
\text { year }^{\text {b }}\end{array}$ \\
\hline BW & 1955 & Stuttgart & 499 & 1.5 & 9 & 4 \\
\hline BAV & 1947 & Munich & n.a. & 3 & 38 & 138 \\
\hline BER & 1992 & Berlin & 785 & 6 & 9 & 180 \\
\hline BB & 1993 & Potsdam & 802 & 6 & 9 & 87 \\
\hline BRE & 1949 & Bremen & 47 & 0 & 7 & 1 \\
\hline HAM & 1953 & Hamburg & 172 & 0 & 9 & 3 \\
\hline HES & 1948 & Wiesbaden & 1007 & 2 & 11 & 113 \\
\hline MW & 1995 & Greifswald & 203 & 1 & 7 & 12 \\
\hline LS & 1957 & Bückeburg & 202 & 0 & 9 & 3 \\
\hline NRW & 1952 & Münster & 737 & 2.0 & 7 & 7 \\
\hline $\mathrm{RP}$ & 1949 & Koblenz & n.a. & n.a. & 9 & 15 \\
\hline SLD & 1959 & Saarbrücken & 26 & 0 & 8 & 4 \\
\hline SAY & 1993 & Leipzig & 179 & 0 & 9 & 110 \\
\hline SAT & 1993 & Dessau-Roßlau & 494 & 5.0 & 7 & 25 \\
\hline SH & 2008 & Schleswig & 66 & 0 & 7 & 2 \\
\hline TH & 1995 & Weimar & 548 & 4 & 9 & 30 \\
\hline $\mathrm{FCC}$ & 1951 & Karlsruhe & $35,866^{\mathrm{c}}$ & $188^{c}$ & 16 & 3534 \\
\hline
\end{tabular}

$B W$ Baden-Württemberg, BAV Bavaria, BER Berlin, BB Brandenburg, BRE Bremen, HAM Hamburg, $H E S$ Hesse, LS Lower Saxony, $M W$ Mecklenburg-West Pomerania, $N R W$ North Rhine-Westphalia, $R P$ Rhineland Palatinate, SLD Saarland, SAY Saxony, SAT Saxony-Anhalt, SH Schleswig-Holstein, $T H$ Thuringia, FCC Federal Constitutional Court

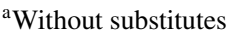

${ }^{\mathrm{b}}$ Average number of incoming cases per year; varying periods

c 2020

who do not hold tenured offices at these courts (Gärditz 2013; Landfried 2015; Reutter 2020b). Justices of these courts are neither on the payroll nor formally employed by the constitutional courts. In their main profession, they are judges at an ordinary court, professors of law at a university, lawyers in a law firm, or have a job in a nonjudicial profession. On average, a German state constitutional court has some ten justices who are elected by state parliaments (Table 1 ). ${ }^{2}$ While this underscores the notion that justices of German state constitutional courts enter office in a democratic and legitimate way, we find some shortcomings with regard to the demographic make-up of these courts. Statistically speaking, justices of subnational constitutional

\footnotetext{
2 There are two justices, one in Bremen and one in Rhineland-Palatinate, who are not elected by the regional parliaments but enter office because they are judges at an ordinary court.
} 
Table 2 State constitutional courts: jurisdictional profiles (in \%). Source Reutter (2020a: 168)

\begin{tabular}{lllllll}
\hline & $\begin{array}{l}\text { Constitutional } \\
\text { complaints }\end{array}$ & $\begin{array}{l}\text { Disputes } \\
\text { between state } \\
\text { organs }\end{array}$ & $\begin{array}{l}\text { Concrete judi- } \\
\text { cial reviews }\end{array}$ & $\begin{array}{l}\text { Abstract judi- } \\
\text { cial reviews }\end{array}$ & $\begin{array}{l}\text { Local constitu- } \\
\text { tional complaints }\end{array}$ & Others \\
\hline BW & 23.0 & 8.6 & 4.7 & 2.3 & 46.3 & 15.2 \\
BAV & 82.6 & 0.6 & 0.0 & 15.4 & - & 1.5 \\
BER & 95.4 & 1.5 & 0.0 & 0.2 & - & 2.8 \\
BB & 55.2 & 1.5 & 0.3 & 0.4 & 20.3 & 22.3 \\
BRE & - & 21.4 & 3.6 & 20.2 & 0.0 & 54.8 \\
HAM & - & 4.2 & 1.6 & 0.0 & - & 94.2 \\
HES & 81.1 & 1.8 & 0.0 & 6.4 & 0.9 & 9.8 \\
MW & 51.1 & 20.3 & 0.4 & 1.3 & 26.8 & 0 \\
LS & - & 11.6 & 1.6 & 7.9 & 55.3 & 23.7 \\
NRW & - & 14.2 & 0.0 & 3.7 & 60.8 & 21.3 \\
RP & 92.6 & 1.5 & - & - & 4.7 & 0 \\
SLD & 61.1 & 7.4 & 2.2 & 2.6 & 10 & 16.6 \\
SAY & 85.8 & 4.1 & 0.2 & 0.6 & 8.1 & 1.2 \\
SAT & 40.0 & 1.8 & 0.7 & 0.4 & 54.3 & 2.8 \\
SH & - & 8.3 & 16.7 & 25.0 & 8.3 & 41.7 \\
TH & 85.2 & 2.3 & 0.7 & 2.3 & 8.2 & 1.2 \\
All & 77.6 & 2.2 & 0.4 & 7.2 & 6.8 & 5.7 \\
\hline & & & & & & \\
\hline
\end{tabular}

courts are mostly male $(85 \%),{ }^{3}$ preside at an ordinary court (54\%) and are around 53 years old when entering office. However, it must be noted that the composition of subnational constitutional courts partly complements the FCCs. We find more women, more lawyers, and at least some justices from nonjudicial professions at the subnational level and some with migration backgrounds (Reutter 2020b).

When it comes to jurisdiction, and according to Flick (2011: 63-66; 2008), the jurisdictions of German state constitutional courts include between six (Constitutional Court of Schleswig-Holstein) and eleven (Bavaria and Saarland) types of proceeding. Five jurisdictional categories exist in all sixteen German state constitutional courts, namely abstract and concrete judicial review, disputes between state organs, check on parliamentary elections (Wahl- und Mandatsprüfung), and on popular initiatives and referenda. Furthermore, except for the city-states of Hamburg and Berlin, in all other German states local constitutional complaints can be brought to the courts. Individual constitutional complaints can be raised in twelve states. ${ }^{4}$ The other ten proceedings that exist in at least one of the states are rarely called

\footnotetext{
${ }^{3}$ This is based on Reutter (2020b), who collected data on nine subnational constitutional courts and 848 justices.

${ }^{4}$ Individual constitutional complaints can be filed at a subnational constitutional court if a person claims that his or her basic rights under the Land constitution have been violated by a public authority. Local communities can also lodge a constitutional complaint if they believe that their basic right to local selfgovernment as laid down in the state constitution has been infringed upon.
} 
upon and play hardly any role in the daily routine of the courts. The workloads of the courts range between 1 and 180 incoming cases per year. However, there are no identifiable patterns with regard to the types of proceeding (Table 2).

This overview shows that subnational constitutional courts are important institutions for German federalism, German democracy, and the rule of law. They are entitled to "say what the law is" in the German states, can invalidate statutory laws passed by the regional parliament, and act as a check on the other branches of government. Thus, they can carry out all the tasks a constitutional court is supposed to accomplish. However, this makes judicialization just an option but not necessarily a factor in politics.

\section{Explaining judicialization: research design, theories and hypotheses}

In common with many other researchers in comparative politics, I use an inferenceoriented research design and quantitative methods in order to find causal links between independent and dependent variables (Geddes 2003). The differences between the German states in size, population, and other aspects do not affect either the status or competencies of the sixteen subnational courts of last resort. The number of incoming cases is in no way linked to factors such as population or economic strength. All state constitutional courts are independent and autonomous institutions. Moreover, the highest courts of the states comply with principles rooted in the civil law tradition. Hence, a most-similar systems research design and linear regression analysis seem to be appropriate tools to address my research question and to test and match theories, data, and applied methods (Geddes 2003; Hirschl 2005; Przeworski and Teune 1970).

A major challenge for research on constitutional courts is to measure or determine the "varying degree of activity of constitutional courts" or judicialization (Hönnige 2011: 352). One problem is that many scholars apply a binary logic because they take into account only whether a ruling has nullified a law (or parts thereof). Such approaches fail to give the contents of rulings their due credit (Pócza et al. 2017). For example, a court might nullify a law just due to formal reasons that can easily be remedied by the legislature. In such cases, the court does hardly limit the competency of a legislature to shape policies. At the same time, a court can validate a law as constitutional but include a number of prescriptions into its ruling. In this case, the law passes as constitutional even though the ruling has relevant implications for the legislature. I therefore needed a more nuanced "textual interpretation" of rulings or a "more sophisticated methodology for systematically mapping the manifold reality of constitutional adjudication, and measuring the strength of judicial decisions" (Pócza et al. 2017: 1557) and in consequence determining the varying degrees of judicialization in the German states. Pócza et al. (2017) have developed one such index that I have modified slightly and which helps to map out the strength of decisions made by constitutional courts (Pócza et al. 2017; Pócza and Dobos 2019: 11-21; Reutter 2019; see "Appendix 1"). This index is composed of four elements. The first, ruling, refers to the basic decision as described in the preamble. It provides information as to whether a law has been found unconstitutional for substantive or 
procedural reasons. The second element, completeness, provides information on whether a law has been completely or only partially nullified. The third, timing, indicates whether the ruling invalidates a law pro futuro, ex nunc, or ex tunc. Finally, a decision can include prescriptions for the legislature. All four elements receive scores: the first one up to seven scores, the second up two scores, the third one up to one score, and the fourth up to two scores. In sum, a decision can receive up to twelve scores. The higher the score the stronger the decision and thus the degree of judicialization. The elements systematically depend on each other, which makes it impossible to explain just one or two elements with the aforementioned variables. Moreover, the index captures only the strength of decisions but tells us nothing about the effects of these rulings on other branches of government. This paper uses this index only to measure the strength of decisions of German subnational constitutional courts and tries to explore causes for these rulings.

There are various theories that strive to explain judicial behaviour and decisionmaking (Rehder 2007; Dyevre 2010; Clayton 1999). Yet as political scientists we all agree that institutions such as norms, organizations, and rules matter (March and Olsen 1989). This truism also applies to the ways in which scholars think about constitutional adjudication and constitutional courts. In 1988, Rogers M. Smith challenged the then dominant attitudinal approach by arguing that courts are institutions that influence how judges make their decisions. Similarly, Gillman and Clayton (1999: 3) pointed out that any attempt to explain judicial behaviour "with reference to beliefs but not to contexts such as institutional settings will inevitably be incomplete". Arguably, this conception does not rule out justices having strategic goals that might play a role in judicial decision-making, but it gives preference to institutional factors in order to explain justices' decision-making. Institutions are thus not just a means for justices to realize some particular strategic goal, as Epstein and Knight (1998: 12; Epstein and Knight 2013) assume. Instead, institutions represent ideas, provide structure, "and prescribe roles for justices. The crucial question, then, is how to define and operationalize these dimensions. I focus on "different types of structures" that "constitute and empower political actors and their environments in important ways, endowing actors with specifiable constraints or capabilities or both' (Gillman and Clayton 1999: 7; cf. also Smith 1988). I try to capture these constraints and/or capabilities in the light of five variables: type of ruling, age of courts, jurisdiction, number of possible terms, and type of proceeding. Furthermore, I will also test whether justices' attitudes might affect decisions taken by subnational constitutional courts.

First, I hypothesize that the type of ruling affects the strength of decisions. A state constitutional court ${ }^{5}$ can either base its decision on a written brief ("nach Aktenlage") which leads to a resolution ("Beschluss") or it can schedule an oral argument ("Anhörung") that precedes a judgement ("Urteil"). Resolutions are handed down if the involved petitioners agree or the court decides unanimously that a hearing is not necessary. In oral arguments, the court may uncover "additional facts bearing" on the case; moreover, they might add legitimacy and improve compliance (Kommers

${ }^{5}$ I exclude cases that fail to be granted a decision on the merits in the first place. 
and Miller 2012: 27). I take it that decisions based on oral arguments (judgements) are more likely to lead to strong decisions. In oral arguments, more evidence can be presented and cases discussed more broadly. In consequence, there is an institutional effect depending on whether a decision is based merely on written briefs or on oral arguments, and this effect has nothing to do with justices' attitudes or strategic goals. Thus, decisions of state constitutional courts that are preceded by oral hearings (Urteile) will be stronger than decisions only based on written briefs (Beschlüsse) (H1).

Second, young courts might hesitate to hand down decisions that could encroach on competencies of other institutions. There is an obvious link between this hypothesis and neo-institutionalist accounts because older courts can mobilize their own sources of legitimacy and can thus make rulings independently from other branches of government, and some evidence supports this assumption. For example, in the early 1950s the status of the German Federal Constitutional Court was a controversial issue disputed between the court and the federal government (Kommers and Miller 2012: 17f.; Lembcke 2015). It is therefore hardly surprising that in its first decade the FCC refrained from rulings that could have challenged the then incumbent government (Brodocz 2006). Similarly, Lembcke (2017: 409-414) viewed the Constitutional Court of Thuringia as a "learning" institution that became more judicially active over time. Thus, stronger decisions should become more likely in older courts (H2).

Third, and as pointed out earlier, many studies on constitutional adjudication assume that the power of a high court is a function of its competencies. Once again, the neo-institutionalist basis of this argument seems clear. The broader the jurisdiction of a court, the greater the impact this court will have on politics regardless of the political or professional motives of the justices sitting on the bench. I too examine whether and how far this applies to subnational constitutional courts, assuming that the broader the jurisdiction of a court the stronger its decisions will be. Thus, $\mathrm{H} 3$ reads as follows: Courts with more competencies will be more active and make stronger decisions than courts with fewer competencies.

Fourth, how and for how long justices are appointed are crucial questions. Alexander Hamilton (1788/2009) wanted to have life tenure for justices of the U.S. Supreme Court to ensure they would serve as an effective check on both executive and legislature. This is clearly an institutionally based argument as it links characteristics of a tenure of a justice with the outcome of a court. The German states did not follow Hamilton's advice but still tried to make sure that justices of high courts can make rulings independently. In twelve states, justices of courts of last resort can serve for more than one term. Overwhelmingly, this option has led to critical comments because the option to serve a further term could make justices subject to political pressure from the government or the majority in parliament (Leunig 2007: 206). In consequence, I assume that a court's decisions will be stronger if justices can just serve one term (H4) because they then lack incentives to accommodate the government or the majority in parliament.

Fifth, it is a common assumption that those proceedings that "provide courts with crucial opportunities to construct constitutional law, to extend jurisprudential techniques of control, and (the same thing) to make policy" (Stone 1994: 447f.) will lead 
to stronger decisions than proceedings that do not provide such opportunities. In the present study, this means that abstract judicial reviews and local constitutional complaints should trigger a greater number of strong decisions. Both proceedings are political in nature and give constitutional courts the chance to shape policies. They may increase the "potential for higher levels of judicialization" (Stone 1994: 448). ${ }^{6}$ This process differs from other proceedings that either address only parts of a law or are just used as a check on whether a law is put into practice in a constitutional manner. In consequence, I presume that abstract judicial reviews and local constitutional complaints will tend to trigger stronger rulings than are given in other proceedings (H5). Once again, it is not extra-legal motives that will trigger strong decisions but the institutional preconditions.

However, I will also test whether factors other than institutional ones have affected decision-making in the three courts in question, as well as exploring if and how far extra-legal motives might have had an impact on decision-making in German state constitutional courts. Two hypotheses will be tested in order to corroborate this assumption. First, Martin Hirsch, a former justice at the Federal Constitutional Court, once claimed that many constitutional justices who served at specialized courts before being appointed to the FCC believe themselves to be better lawmakers than the proper legislator (Lamprecht and Malinowski 1978: 60). Such an attitude is even more likely to prevail in subnational constitutional courts because some part-time justices are, in their main profession, judges at an ordinary court. In consequence, these justices can shape the law that they have to apply to facts as judges at specialized courts. Thus, I assume that a high share of professional judges will trigger stronger decisions and thus cause judicialization (H6). If corroborated, this hypothesis would point to strategic motives and goals of justices.

Second and similarly, in behaviourist approaches political attitudes are supposed to be a major (if not the only) cause for explaining judicial behaviour (Segal and Spaeth 2002; Landfried 1984; Hönnige 2007). I will also examine whether political affiliations have any impact on the strength of decisions or on judicialization. More specifically, I assume that justices nominated by parties in opposition will tend to make stronger decisions because they might feel loyalty to the party that has picked and nominated him or her or because they endorse other political values than those professed by the incumbent government. These justices might be inclined to limit the room for manoeuvre of the executive and thus make strong decisions (H7).

In sum, I will test seven hypotheses of which five, if corroborated, would underscore institutional theories ( $\mathrm{H} 1, \mathrm{H} 2, \mathrm{H} 3, \mathrm{H} 4, \mathrm{H} 5)$ and two, if confirmed, would point to the fact that strategic goals of justices would at least partly explain the outcome (H6, H7).

6 Stone refers here only to abstract judicial review. 
Table 3 Independent variables: descriptive statistics. Source Author's compilation

\begin{tabular}{llcccr}
\hline & $N$ & Mean & SD & Minimum & Maximum \\
\hline (1) Type of ruling & 245 & 1.37 & 0.48 & 1.00 & 2.00 \\
(2) Age of court & 245 & 8.35 & 6.22 & 0.17 & 23.82 \\
(3) Jurisdiction & 245 & 8.57 & 3.08 & 0.07 & 14.43 \\
(4) Possible terms & 245 & 1.31 & 0.47 & 1.00 & 2.00 \\
(5) Type of proceeding & 245 & 1.27 & 0.44 & 1.00 & 2.00 \\
(6) Professional judges & 245 & 44.27 & 18.18 & 14.29 & 100.00 \\
(7) Oppositional judges & 245 & 36.37 & 14.31 & 0.00 & 71.43 \\
\hline
\end{tabular}

\section{Data and variables}

Case selection and data collection are as crucial for empirical research as theories and hypotheses (Geddes 2003: 131-174; Epstein and Winter 2014: 63-94), and this of course applies to the present study. In consequence, I will first describe the process of case selection (a) and in a second step how I operationalized the independent (b) and dependent (c) variables. Table 3 outlines the independent variables used in the regression analysis.

(a) Case selection For this paper, two criteria underpinned the case selection and consequently defined the number of decisions included in the analysis. First, I needed to select courts, and comparability and availability of data were crucial in this respect. Four states established their constitutional court prior to the passing of the Basic Law in 1949, five in the 1950s, and the five formerly East German states, Berlin, and Schleswig-Holstein after unification (Table 1). As pointed out, subnational constitutional courts are not only supposed to be a defining feature of the federal model but also reflect historical circumstances. However, the fall of the Wall and subsequent German unification gave rise to a kind of "constitutional fervour" (Delledonne 2012: 303) that led to new constitutions and triggered the updating of old constitutions that were amended by new fundamental rights and policy goals (Reutter and Lorenz 2016). This also affected the way constitution-makers conceived the role of constitutional courts. Thus, I chose only courts that were established in a period in which the possibility of constitutional review was considered as crucial for the stability of the democratic system. Moreover, I needed information on the justices' main professions and political attitudes. Data on their main professions can be found in parliamentary records, the Handbuch der Justiz (Deutscher Richterbund 1993ff), court websites and other sources. However, information on political attitudes is more difficult to glean. As there exist no records on how judges vote in courts on crucial issues, I assume that the political leaning of nominating parliamentary parties reflects justices' political attitudes. However, only a few regional parliaments report on the parliamentary groups that nominate candidates for justices at a constitutional court. This lack of information forced me to limit my analysis to the courts of Berlin, Brandenburg, and Schleswig-Holstein (Flick Witzig 2017; Lorenz 2017; Reutter 2017). 
All three were established in the post-unification period and provide the necessary data for this analysis.

Second, and as previously pointed out, I will apply the aforementioned strength index. Pócza and Dobos (2019: 25f.), who were part of this research effort, recommend an exclusive focus on politically "salient decisions". However, such an approach is difficult to take and open to subjective interpretation. Hence, I selected a different approach and included only decisions that the courts themselves found important enough to be featured in an official series published each year by several state constitutional courts (LVerfGE 1993ff). In the end, this left me with 245 decisions made by the three aforementioned constitutional courts.

(b) Independent variables Two variables (in H6 and H7) refer to the main profession of the justices and their political preferences. Regarding the latter, I assume that a justice would endorse the policies of the party that has nominated him or her for the court in the first place. ${ }^{7}$ Admittedly, this is not an ideal indicator but is one that has also been applied in other studies (Pritchett 1948; Epstein et al. 2013: 101-151; Landfried 1984). Furthermore, I had to break down the composition of the court for each decision and calculate the proportion of justices who had been nominated by a party in opposition at the time of the decision. I proceeded in the same manner with regard to the main profession of justices. As pointed out, all justices of state constitutional courts serve on an honorary and part-time basis, and they make their living in their main professions. Once again, I identified the justices who took a vote on a court's decision and calculated the proportion of professional judges for each ruling.

I captured the institutional dimensions with five variables:

- Type of ruling As there are only two types of decision made by subnational constitutional courts, I created a categorical variable (dummy). I assume that a judgement ("2") will cause stronger decisions than a resolution ("1"). The decisions provide the information for the coding.

- Age of court This continuous variable measures the period between the election of the first justices to a constitutional court and the date when a decision of a court has been handed down. The data can be found in parliamentary records and in the decisions handed down by the courts.

- Jurisdiction Lijphart (1999: 225) has pointed out that it is not only the formal existence of the court's competencies that matters but also "the frequency of its use by the courts". I followed Lijphart's two-dimensional concept. To calculate the continuous variable, I combined two factors, namely the number of formal competencies and the number of incoming cases per year. This reads as follows: Jurisdiction $=$ number of legal competencies $\times$ number of incoming cases per

\footnotetext{
7 Arguably, such an approach creates problems because parliamentary parties have to take various criteria into account and the ideological affinity of a future justice with a particular party's platform is just one aspect influencing party deliberations. For example, a justice might have a general leaning towards a party but this does not mean that he or she endorses the entire platform of that party. Additionally, in the court environment, reports show that judicial reasoning tends to outweigh political preference.
} 
Table 4 Three state constitutional courts, and causes of judicialization (bootstrapping)

\begin{tabular}{|c|c|c|c|c|c|c|}
\hline Number of obs & & $=$ & & & & 245 \\
\hline Replications & & $=$ & & & & 10,000 \\
\hline Wald chi $^{2}(7)$ & & $=$ & & & & 66.82 \\
\hline Prob $>$ chi $^{2}$ & & $=$ & & & & 0.0000 \\
\hline R-squared & & $=$ & & & & 0.2987 \\
\hline Adj R-squared & & $=$ & & & & 0.2780 \\
\hline Root MSE & & $=$ & & & & 1.7008 \\
\hline Strength & Observed coeff. & Bootstrap SE & $z$ & $P>|z|$ & \multicolumn{2}{|c|}{ Normal-based $(95 \% \mathrm{CI})$} \\
\hline (1) Type of decision & 1.362864 & 0.2694224 & 5.06 & 0.000 & 0.8348062 & 1.890922 \\
\hline (2) Age of court & -0.0496552 & 0.031692 & -1.57 & 0.117 & -0.1117703 & 0.0124599 \\
\hline (3) Jurisdiction & 0.1651378 & 0.0492279 & 3.35 & 0.001 & 0.068653 & 0.2616227 \\
\hline (4) Possible terms & -1.044564 & 0.3786047 & -2.76 & 0.006 & -1.786616 & -0.3025128 \\
\hline (5) Type of proceeding & 1.009668 & 0.3370616 & 3.00 & 0.003 & 0.3490396 & 1.670297 \\
\hline (6) Professional judges & 0.0123281 & 0.0073403 & 1.68 & 0.093 & -0.0020586 & 0.0267147 \\
\hline (7) Oppositional judges & 0.0212685 & 0.0100347 & 2.12 & 0.034 & 0.0016009 & 0.0409361 \\
\hline Const. & -3.185003 & 0.8790931 & -3.62 & 0.000 & -4.907994 & -1.462012 \\
\hline
\end{tabular}

I again used Stata 16.1

year/100. The number of legal competencies can be found in Flick (2011: 63-66) and Reutter (2020a: 164f.).

- Possible terms Justices serving on the constitutional court of Schleswig-Holstein can stay in office for two terms. Justices of the high courts of Berlin and Brandenburg serve just one term. However, the first nine justices elected to the high court in Brandenburg were entitled to a second term. In order to capture the differences, I created a dummy. I presume that a possible re-appointment would lead to weaker decisions. Thus, I coded the dummy as follows: $1=$ more than one term possible; 2 =just one term, and this is expected to result in a positive coefficient.

- Type of proceeding As pointed out, many studies assume judicialization is a function of a court's power to invalidate laws. With regard to German subnational constitutional courts, this notably applies to abstract judicial review and to local constitutional complaints. The courts report in their rulings on the type of decision they make. I again created a dummy, which I coded as follows: $2=$ abstract judicial reviews and local constitutional complaints; $1=$ all other proceedings. This should also produce a positive coefficient.

(c) Dependent variable As pointed out I want to explain the strength of decisions that I try to map out with the aforementioned index. However, even though I only picked "salient decisions" for my analysis none of the 245 decisions included in this study received the maximum score of twelve points. The scores range between 0 and 8.5; their mean value is 0.9 (standard deviation is 2.0). In sum, these findings do not support the assumption that rulings of subnational constitutional courts might encroach upon 
the competencies of other branches of government. In consequence, this finding shifts the focus of the research from explaining judicialization to exploring causes of judicial decision-making.

\section{Analysing causes of judicial decision-making: linear regression}

In the words of Lee Epstein and Andrew D. Martin, a linear regression model is the "workhorse of empirical legal studies", notably because the model "allows us to include more than one independent variable in our analysis [...] and draw causal inferences" (Epstein and Winter 2014: 173). However, as two requirements for a regression analysis (see "Appendix 2") are not met, I used bootstrapping as a nonparametric regression. Bootstrapping does not assume a normal distribution of the residuals, allows a variance in homoscedacity, and is less sensitive to outliers (Table 4). In bootstrapping, the original sample is used for creating new samples of the same size (the number of replications in this study is 10,000). Eventually, with this approach it is possible to replace the theoretical distribution function by an empirically created one (Efron 1979). As expected, bootstrapping increased the standard errors and decreased significance for some variables. Based on this output, I can draw the following conclusions.

First, I checked if the overall model shows significance. In my model, the F-value is large and significant below 0.05 (rounded at 0.000). The coefficient of determination $\left(r^{2}\right)$ in this model explains almost $30 \%$ of the amount of variances of the dependent variable (adj. $r^{2}=0.2780$ ). According to Cohen (1992), this represents a medium-sized effect. The two tables provide the results of the analysis and help to decide which variables have significant influence on the dependent variable.

There are seven independent variables in the model. Both the age of the court and the share of professional judges are not significant and have no impact on the strength of decisions. In consequence, the hypotheses $\mathrm{H} 2$ and $\mathrm{H} 6$ could not be confirmed. The other variables are all significant at least at the 5\% level but explain to different degrees the variance of the dependent variable. The type of decision shows the strongest effect (adj $r^{2}=0.2009$ ) followed by the type of proceeding (adj $\left.r^{2}=0.1027\right)$ and the jurisdiction $\left(\operatorname{adj} . r^{2}=0.0344\right)$. The variable that captures the number of possible terms is significant but shows a negative coefficient, meaning that if a justice can be re-appointed he or she will tend to make stronger decisions. The behaviourist variable that is significant (at the 5\% level) is the proportion of justices nominated by a party in opposition. However, this has no effect on the variance of the dependent variable as it triggers only an adjusted $r^{2}$ of -0.0040 . In sum, the analysis strongly underscores the influence of institutional factors.

\section{Conclusion}

\section{Going beyond judicialization}

Based on these findings, I can draw four tentative conclusions that pertain to this paper's research question about the causes and consequences of judicial 
decision-making in German subnational constitutional courts. First, to rule with a constitutional court does not necessarily mean to rule like a constitutional court, as Stone (1994; Stone Sweet 2000) and others have claimed. At least as far as German state constitutional courts are concerned, we find only few rulings that would qualify as strong enough to encroach upon the competencies of the legislature. Most rulings had no effect whatsoever on the legislature or on the government. In consequence, there is no simple causal link between the existence of a high court and judicialization. The findings rather indicate that we must take the type of constitutional court into account as well as the context in which these courts operate (Clayton 1999).

Second, the analysis of 245 decisions of three constitutional courts supports neo-institutionalist approaches. The study failed to provide any evidence for the assumption that political preferences or professional attitudes have had any impact on the strength of decisions of German subnational constitutional courts. Moreover, the analysis shows that two factors are most important to explain the strength of decisions: namely, the type of decision and the type of proceeding.

Third, the study has raised some methodological questions, as well. Notably, the operationalization of variables is still a major challenge. This includes the enduring debate around how to capture political attitudes of justices but also how to measure the jurisdictions of constitutional courts, as Hönnige (2011) has pointed out. Furthermore, I believe that the strength index used in this paper effectively captures "the varying degree of activity of constitutional courts" (Hönnige 2011: 352). The sophisticated measure not only includes all decisions declaring a law unconstitutional but also "allows for a more nuanced consideration of the strength of the judicial decisions" (Pócza et al. 2017: 1563). The complex reality of constitutional adjudication requires such a methodology. Pócza et al. (2017) have shown that the index they developed can help to better map out the effects of judicial decision-making and compare constitutional courts across nations than dichotomous measures that can just separate positive from negative decisions of constitutional courts. This clearly marks a huge step forward in the comparative research on constitutional adjudication. Still, we need more studies by other researchers to test whether this index is robust enough to capture the varying degrees of judicial activity undertaken by courts. Moreover, the index tells us nothing about the effects of these rulings on other branches of government. So, we do not know if and in what way state legislatures reacted on rulings of constitutional court. We just know that in some cases they should have changed a law more or less profoundly.

Finally, "going beyond judicialization" (Hönnige 2011) means moving towards judicial decision-making. In other words, it is still an open question as to how to link micro-level causes of judicial decision-making with macro-level effects of constitutional adjudication. These two dimensions of constitutional adjudication seem to require different theoretical and empirical approaches. It will be up to future research to reconcile these two perspectives on constitutional adjudication.

Acknowledgements This work was supported by the Deutsche Forschungsgemeinschaft under Grant RE 1376/4-1; AOBJ 644495.

Open Access This article is licensed under a Creative Commons Attribution 4.0 International License, which permits use, sharing, adaptation, distribution and reproduction in any medium or format, as long as you give appropriate credit to the original author(s) and the source, provide a link to the Creative Commons 
licence, and indicate if changes were made. The images or other third party material in this article are included in the article's Creative Commons licence, unless indicated otherwise in a credit line to the material. If material is not included in the article's Creative Commons licence and your intended use is not permitted by statutory regulation or exceeds the permitted use, you will need to obtain permission directly from the copyright holder. To view a copy of this licence, visit http://creativecommons.org/licenses/by/4.0/.

\section{Appendix 1: Strength of judicial decisions: components and elements}

\begin{tabular}{|c|c|c|c|c|c|c|}
\hline Ruling & $\begin{array}{l}\text { Rejection or } \\
\text { refusal }(0.0)\end{array}$ & $\begin{array}{l}\text { Unconstitu- } \\
\text { tionality by } \\
\text { legislative } \\
\text { omission } \\
(0.25)\end{array}$ & $\begin{array}{l}\text { Procedural } \\
\text { unconsti- } \\
\text { tutionality } \\
(1.0)\end{array}$ & $\begin{array}{l}\text { Consti- } \\
\text { tutional } \\
\text { require- } \\
\text { ments }(2.0)\end{array}$ & $\begin{array}{l}\text { Substantive } \\
\text { unconsti- } \\
\text { tutionality } \\
(5.0)\end{array}$ & $\begin{array}{l}\text { Constitutional } \\
\text { interpretation } \\
\text { in abstracto } \\
(7.0)\end{array}$ \\
\hline $\begin{array}{l}\text { Complete- } \\
\text { ness }\end{array}$ & \multicolumn{2}{|c|}{$\begin{array}{l}\text { Qualitative partial annul- } \\
\text { ment }(0.0)\end{array}$} & \multicolumn{2}{|c|}{$\begin{array}{l}\text { Quantitative partial annul- } \\
\text { ment (1.0) }\end{array}$} & \multicolumn{2}{|c|}{ Complete annulment (2.0) } \\
\hline Timing & \multicolumn{2}{|c|}{ Pro futuro $(0.0)$} & \multicolumn{2}{|c|}{ Ex nunc $(0.5)$} & \multicolumn{2}{|l|}{ Ex tunc (1.0) } \\
\hline Prescription & \multicolumn{2}{|c|}{ No prescription $(0.0)$} & \multicolumn{2}{|c|}{$\begin{array}{l}\text { Non-binding prescription } \\
\text { (1.0) }\end{array}$} & \multicolumn{2}{|c|}{$\begin{array}{l}\text { Directive/binding prescrip- } \\
\text { tion }(2.0)\end{array}$} \\
\hline
\end{tabular}

\section{Appendix 2: Three state constitutional courts and causes of judicialization (linear regression)}

\begin{tabular}{|c|c|c|c|c|c|c|c|c|c|c|}
\hline Source & \multicolumn{2}{|l|}{ SS } & \multicolumn{2}{|l|}{$d f$} & \multicolumn{2}{|l|}{ MS } & \multicolumn{2}{|c|}{ Number of obs } & $=$ & 245 \\
\hline Model & \multicolumn{2}{|c|}{292.073988} & \multicolumn{2}{|c|}{7} & \multicolumn{2}{|c|}{41.7248554} & \multicolumn{2}{|c|}{$F(7237)$} & $=$ & 14.42 \\
\hline Residual & \multicolumn{2}{|c|}{685.609685} & \multicolumn{2}{|c|}{237} & \multicolumn{2}{|c|}{2.89286787} & \multicolumn{2}{|c|}{ Prob $>F$} & $=$ & 0.0000 \\
\hline \multirow[t]{3}{*}{ Total } & \multicolumn{2}{|c|}{977.683673} & \multicolumn{2}{|l|}{244} & \multicolumn{2}{|c|}{4.0069003} & \multirow{2}{*}{\multicolumn{2}{|c|}{$\begin{array}{l}\text { R-squared } \\
\text { Adj R-squared }\end{array}$}} & $=$ & 0.2987 \\
\hline & & & & & & & & & $=$ & 0.2780 \\
\hline & & & & & & & & & $=$ & 1.7008 \\
\hline \multicolumn{2}{|l|}{ Strength } & Coeff. & & SI & & $t$ & $P>|t|$ & {$[95 \% \mathrm{CI}]$} & & VIF \\
\hline \multicolumn{2}{|c|}{ (1) Type of decision } & 1.36 & 864 & & 55922 & 5.33 & 0.000 & 0.8593416 & 1.866387 & 1292 \\
\hline \multicolumn{2}{|c|}{ (2) Age of court } & -0.04 & 6552 & & 262613 & -1.89 & 0.060 & -0.1013905 & 0.0020801 & 12254 \\
\hline \multicolumn{2}{|c|}{ (3) Jurisdiction } & 0.16 & 1378 & & 100889 & 4.12 & 0.000 & 0.0861618 & 0.2441139 & 1288 \\
\hline \multicolumn{2}{|c|}{ (4) Possible terms } & -1.02 & 564 & & 30531 & -2.96 & 0.003 & -1.740088 & -0.3490413 & 32277 \\
\hline \multicolumn{2}{|c|}{ (5) Type of proceeding } & 1.00 & 668 & & 324469 & 3.57 & 0.000 & 0.453241 & 1.566095 & 1317 \\
\hline \multicolumn{2}{|c|}{ (6) Professional judges } & 0.01 & 3281 & & 75604 & 1.63 & 0.104 & -0.0025661 & 0.0272223 & 31666 \\
\hline \multicolumn{2}{|c|}{$\begin{array}{l}\text { (7) Oppositional } \\
\text { judges }\end{array}$} & 0.02 & 2685 & & 98249 & 2.16 & 0.031 & 0.0019131 & 0.0406239 & 1317 \\
\hline \multicolumn{2}{|l|}{ Const } & -3.18 & 003 & & 517698 & -3.74 & 0.000 & -4.86301 & -1.506996 & 1594 \\
\hline
\end{tabular}

I used the statistical programme Stata 16.1 and ran a linear multiple regression 
Any regression model makes some assumptions that should be fulfilled. First, independent variables should not correlate too strongly (multicollinearity). This condition is fulfilled as the VIF values are all well below ten. Moreover, residuals should not show autocorrelation. Once again, this criterion is met as the Durbin-Watson-Test produces a value of 1.812 which is close enough to the ideal point of 2 . However, the residuals fail to be normally distributed and there is heteroscedacity.

\section{References}

Brodocz, A. 2006. Balancen der Macht. Über die Deutungsmacht des Bundesverfassungsgerichts in den 50er Jahren. In Die Deutungsmacht der Verfassungsgerichtsbarkeit, ed. H. Vorländer, 175-204. Wiesbaden: VS Verlag.

Brouard, S., and C. Hönnige. 2017. Constitutional Courts as Veto Players: Lessons from the United States, France and Germany. European Journal of Political Research 56 (3): 529-552.

Clayton, C.W. 1999. The Supreme Court and Political Jurisprudence: New and Old Institutionalisms. In Supreme Court Decision-Making. New Institutionalist Approaches, ed. C.W. Clayton and H. Gillman, 15-42. Chicago and London: The University of Chicago Press.

Cohen, J. 1992. A Power Primer. Psychological Bulletin 112 (1): 155-159.

Delledonne, G. 2012. Subnational Constitutionalism: A Matter of Review. Perspectives on Federalism 4(2): 294-316.

Dyevre, A. 2010. Unifiying the Field of Comparative Judicial Politics: Towards a General Theory of Judicial Behaviour. European Political Science Review 2 (2): 297-327.

Efron, B. 1979. Bootstrap Methods: Another Look at the Jackknife. The Annals of Statistics 7 (1): 1-26. https://doi.org/10.1214/aos/1176344552.

Epstein, L. and J. Knight. 1998. The Choices Judges Make. Washington, D.C.: CQ Press.

Epstein, L., and J. Knight. 2013. Reconsidering Judicial Preferences. Annual Review of Political Science 16: 11-31.

Epstein, L., and A.D. Winter. 2014. An Introduction to Empirical Legal Research. Oxford: University Press.

Epstein, L., W.M. Landes, and R.A. Posner. 2013. The Behavior of Federal Judges: A Theoretical and Empirical Study of Rational Choice. Cambridge and London: Harvard University Press.

Federal Constitutional Court. 2020. Annual Statistics 2018, available at https://www.bundesverfassun gsgericht.de/SharedDocs/Downloads/EN/Statistik/statistics_2018.pdf?_blob=publicationFile $\& \mathrm{v}=4$.

Flick, M. 2008. Landesverfassungsgerichtsbarkeit. In Die Demokratien der deutschen Bundesländer: Politische Institutionen im Vergleich, ed. M. Freitag and A. Vatter, 237-256. Opladen: Verlag Barbara Budrich.

Flick, M. 2011. Organstreitverfahren vor den Landesverfassungsgerichten. Bern: Peter Lang.

Flick Witzig, M. 2017. Das Schleswig-Holsteinische Landesverfassungsgericht. In Landesverfassungsgerichte: Entwicklung-Aufbau-Funktionen, ed. W. Reutter, 371-388. Wiesbaden: Springer VS.

Gärditz, K.F. 2013. Landesverfassungsrichter: Zur personalen Dimension der Landesverfassungsgerichtsbarkeit. Jahrbuch des öffentlichen Rechts der Gegenwart 61: 449-493.

Geddes, B. 2003. Paradigms and Sand Castles: Theory Building and Research Design in Comparative Politics. Ann Arbor: University of Michigan Press.

Gibson, J.L., G.A. Caldeira, and V.A. Baird. 1998. On the Legitimacy of National High Courts. American Political Science Review 92 (2): 353-358.

Gillman, H., and C.W. Clayton. 1999. Beyond Judicial Attitudes: Institutional Approaches to Supreme Court Decision-Making. In Supreme Court Decision-Making: New Institutionalist Approaches, ed. C.W. Clayton and H. Gillman, 1-12. Chicago and London: The University of Chicago Press.

Deutscher Richterbund (ed.) (1993ff.) Handbuch der Justiz: Die Träger und Organe der rechtsprechenden Gewalt in der Bundesrepublik Deutschland. Heidelberg: C.F. Müller. 
Hamilton, A. 1788/2009. Federalist No. 78. In Federalist Papers, ed. I. Shapiro, 391-397. New Haven: Yale University Press.

Hirschl, R. 2004. The Political Origins of the New Constitutionalism. Indiana Journal of Global Legal Studies 11 (1): 71-108.

Hirschl, R. 2005. The Question of Case Selection in Comparative Constitutional Law. American Journal of Comparative Law 53(1):125-155.

Hirschl, R. 2007. Towards Juristocracy: The Origins and Consequences of the New Constitutionalism. Cambridge and London: Harvard University Press.

Hönnige, C. 2007. Verfassungsgericht, Regierung und Opposition: Eine vergleichende Analyse eines Spannungsdreiecks. Wiesbaden: VS Verlag für Sozialwissenschaften.

Hönnige, C. 2011. Beyond Judicialization: Why We Need More Comparative Research About Constitutional Courts. European Political Science 10 (3): 346-358.

Kommers, D.P., and R.A. Miller. 2012. The Constitutional Jurisprudence of the Federal Republic of Germany, 3rd ed. Durham and London: Duke University Press.

Lamprecht, W., and W. Malinowski. 1978. Richter machen Politik: Auftrag und Anspruch des Bundesverfassungsgerichts. Frankfurt/Main: Fischer.

Landfried, C. 1984. Bundesverfassungsgericht und Gesetzgeber. Baden-Baden: Nomos.

Landfried, C. 2015. Die Wahl der Bundesverfassungsrichter und ihre Folgen für die Legitimität der Verfassungsgerichtsbarkeit. In Handbuch Bundesverfassungsgericht im politischen System, ed. R. Chr. van Ooyen and M.H.W. Möllers, 369-387. Wiesbaden: Springer VS.

Lembcke, O.W. 2015. Das Bundesverfassungsgericht und die Regierung Adenauer-vom Streit um den Status, zur Anerkennung der Autorität. In Handbuch Bundesverfassungsgericht im politischen System, ed. Chr. van Ooyen and M.H.W. Möllers, 231-244. Wiesbaden: Springer VS, 2nd ed.

Lembcke, O.W. 2017. Thüringer Verfassungsgerichtshof. In Landesverfassungsgerichte: EntwicklungAufbau-Funktionen, ed. W. Reutter, 389-420. Wiesbaden: Springer VS.

Leunig, S. 2007. Die Regierungssysteme der deutschen Länder im Vergleich. Opladen \& Farmington Hills: Verlag Barbara Budrich.

Lijphart, A. 1971. Comparative Politics and the Comparative Method. American Political Science Review 65 (3): 682-693.

Lijphart, A. 1999. Patterns of Democracy: Government Forms and Performance in Thirty-Six Countries. New Haven and London: Yale University Press.

Lorenz, A. 2017. Das Verfassungsgericht des Landes Brandenburg als politisiertes Organ. In Landesverfassungsgerichte: Entwicklung-Aufbau-Funktionen, ed. W. Reutter, 105-128. Wiesbaden: Springer VS.

LverfGE. 1993ff. Entscheidungen der Verfassungsgerichte der Länder, ed. by members of the courts, vol. 1-26, Berlin: Walter de Gruyter.

March, J.G., and J.P. Olsen. 1989. Rediscovering Institutions: The Organizational Basis of Politics. New York, NY: Free Press.

Pócza, K., and G. Dobos. 2019. Research Methodology. In Constitutional Politics and the Judiciary: Decision-Making in Central and Eastern Europe, ed. K. Pócza, 8-31. London: Routledge.

Pócza, K., G. Dobos, and A. Gyulai. 2017. How to Measure the Strength of Judicial Decisions: A Methodological Framework. German Law Journal 18(6): 1557-1586.

Pritchett, C.H. 1948. The Roosevelt Court: A Study in Judicial Politics and Values 1937-1947. New Orleans: Quid Pro Books.

Przeworski, A., and H. Teune. 1970. The Logic of Comparative Social Inquiry. Malabar: Krieger Publishing.

Rehder, B. 2007. What is Political about Jurisprudence: Courts, Politics and Political Science in Europe and the United States. Discussion Paper 07/5, Cologne: MPIfG.

Reutter, W. 2017. Der Verfassungsgerichtshof des Landes Berlin. In Landesverfassungsgerichte: Entwicklung-Aufbau-Funktionen, ed. W. Reutter, 77-104. Wiesbaden: Springer VS.

Reutter, W. 2019. Constitutional Adjudication and Judicial Activism in a German Land. Perspectives on Federalism 11(2):95-125.

Reutter, W. 2020a. Zum Status der Landesverfassungsgerichte als Verfassungsorgane. In Verfassungsgerichtsbarkeit in Bundesländern: Theoretische Perspektiven, methodische Überlegungen und empirische Befunde, ed. W. Reutter, 155-174. Wiesbaden: Springer VS.

Reutter, W. 2020b. Verfassungsrichterinnen und Verfassungsrichter: zur personalen Dimension der Verfassungsgerichtsbarkeit in Bundesländern. In Verfassungsgerichtsbarkeit in Bundesländern: 
Theoretische Perspektiven, methodische Überlegungen und empirische Befunde, ed. W. Reutter, 203-233. Wiesbaden: Springer VS.

Reutter, W. and A. Lorenz. 2016. Explaining the Frequency of Constitutional Change in the German Länder: Institutional and Party Factors. Publius: The Journal of Federalism 46(1): 103-127.

Segal, J.A., and H.J. Spaeth. 2002. The Supreme Court and the Attitudinal Model Revisited. Cambridge: Cambridge University Press.

Smith, R.M. 1988. Political Jurisprudence, The "New Institutionalism", and the Future of Public Law. American Political Science Review 82 (1): 89-108.

Starck, C. 1983. Der verfassungsrechtliche Status der Landesverfassungsgerichte. In Landesverfassungsgerichtsbarkeit. Teilband I: Geschichte, Organisation, Rechtsvergleichung, ed. C. Starck and K. Stern, 155-182. Baden-Baden: Nomos.

Stone, A. 1994. Judging Socialist Reform: The Politics of Coordinate Construction in France and Germany. Comparative Political Studies 26 (4): 443-469.

Stone Sweet, A. 2000. Governing with Judges. Constitutional Politics in Europe. Oxford: Oxford University Press.

Tsebelis, G. 2002. Veto Players: How Political Institutions Work. Princeton: University Press.

Wittreck, F. 2006. Die Verwaltung der Dritten Gewalt. Tübingen: Mohr Siebeck.

Publisher's Note Springer Nature remains neutral with regard to jurisdictional claims in published maps and institutional affiliations.

Werner Reutter has worked as a research fellow at the Social Science Research Centre Berlin, the Free University and as an assistant professor at the Humboldt University Berlin. He was visiting professor in Berlin, Bonn and Jena, and Visiting Associate Professor at the University of Minnesota (USA). He has published books and articles on interest groups, the international trade union movement, constitutional politics, German politics, German state parliaments and German state constitutional courts. Among his books are: Möglichkeiten und Grenzen internationaler Gewerkschaftspolitik (1998), Verbände und Interessengruppen in den Ländern der Europäischen Union. 2nd ed. (2012); Germany on the Road to "Normalcy": Policies and Politics of the Red-Green Federal Government (2004) (editor); Landesparlamentarismus. Geschichte-Struktur-Funktionen. 2nd ed. (2012) (co-editor); Landesverfassungsgerichte. Entwicklung-Aufbau Funktionen (2017) (editor). 